\title{
SOME EFFECTS OF WINTER GRAZING MANAGEMENT ON WINTER AND SUBSEQUENT SPRING PRODUCTIVITY OF A RYEGRASS- WHITE CLOVER PASTURE
}

\author{
A. J. Harris and K. R. Brown \\ Grasslands Division, DSIR, Gore
}

\section{INTRODUCTION}

THE NEED for greater efficiency in pasture utilization is becoming more marked as stock numbers rise. In Southland, much of the increase is arising from higher stock concentrations and rates of almost 10 sheep per acre are known (Lawlor, 1970), although the average is considerably lower.

Southland is characterized by winters which are cold, with low insolation and low evapotranspiration rates compared with much of New Zealand. Pasture production approximates $10 \mathrm{lb}$ DM per acre per day in June-July (Harris, unpublished data), and supplementary feeding (usually brassica crops, hay or silage) is necessary. There is greater awareness of the need to increase the plane of nutrition of the pregnant ewe as parturition approaches (Wallace, 1959), and it has been demonstrated (Harris, 1960) that this can be achieved by judicious use of pasture. However, many who are farming low-stocked units pay little attention to these tenets and graze pasture indiscriminately.

This paper reports the effects on winter production of three contrasting uses of pasture and examines the effects on subsequent spring productivity.

\section{EXPERIMENTAL}

The experiment was carried out at Grasslands Division, DSIR, Gore (lat. $46^{\circ} 06^{\prime}$ S.) on Mataura silt loam (Cutler, 1950 ), using pasture which had been sown to a mixture of 'Grasslands Ariki' ryegrass (Lolium hybrid) and 'Grasslands Huia' white clover (Trifolium repens L.) in December, 1966. Annual autumn applications of $3 \mathrm{cwt}$ serpentinesuperphosphate and $1 \mathrm{cwt}$ muriate of potash per acre were made, while pasture insects were controlled by fenitrothion or DDT. 
Treatments for the experiment were as follows:

(1) Rotationally grazed 3 to 4 in. down to 1 in. (defoliated when the likelihood of treading damage would be minimal). This is referred to subsequently as Moderate Grazing.

(2) Grazed regardless of conditions fortnightly to $\frac{1}{2}$ in. or less (Hard Grazing).

(3) Treated as (1) above until mid-May, when 1 cwt urea per acre was applied, then not grazed until mid-August (ASP.).

The trial was in two parallel parts:

(a) Grazing: Paddocks, 3 treatments $\mathrm{X} 4$ replications. Size $88 \mathrm{ft}$ X $33 \mathrm{ft}$.

(b) Treading: Race technique after Edmond (1958) . 3 treatments $X 2$ treading rates (treading and no treading as split plot) $X 5$ replications. Sub-plot size $20 \mathrm{ft}$ $\mathrm{x} 5 \mathrm{ft}$.

Grazing and treading were carried out on the same day and the number of sheep used for grazing for $24 \mathrm{hr}$ determined the number of sheep passages in the treading experiment with half the number of these passages carried out at commencement and the remainder at termination of grazing to make some allowance for the possibility of weather change.

Following a four-week pretreatment period, measurements of the winter phase of the experiment commenced on May 14 and terminated on August 20, 1969. Spring recovery was measured during the period August 22 to October 7, 1969.

Pasture yields were determined in paddocks by bulking the herbage cut with hand shears from 10 randomly sited $2 \mathrm{sq} \mathrm{ft}$ quadrats per paddock and 3 per treading sub-plot. Sub-samples for dry matter determinations and botanical analyses "were taken from each paddock or sub-plot. Samples from the hard-grazed plots were washed before oven drying to remove adhering mud.

Spring recovery was measured by cutting at approximately weekly intervals $2 \mathrm{ft}$ wide strips with a reel mower through $20 \mathrm{ft}$ plots in the paddocks and $3 \mathrm{ft} 6 \mathrm{in}$. across treading sub-plots. Samples for botanical separations were taken with hand shears adjacent to the mown area.

Grass tiller and clover bud measurements were made at the commencement of each period and at termination using the technique of Mitchell and Glenday (1958) and counting 15 plugs per plot, 


\section{RESULTS}

Pasture yields from both grazing and treading treatments are presented in Table 1.

TABLE 1: YIELDS OF PASTURE HERBAGE (lb DM per acre) FOR THE WINTER PERIOD, MAY 14, 1969, to AUGUST 20, 1969

\begin{tabular}{|c|c|c|c|c|c|c|}
\hline & & & & reading & & \\
\hline & Treatment & Tródden & & רtrodden & Mean & Grazing \\
\hline To & AL HERBAGE & & & & & \\
\hline & Moderate grazing & 1,220 & & 1,270 & 1,245 & 1,010 \\
\hline & Hard grazing & 630 & & 1,350 & 990 & 590 \\
\hline & A.S.P. & 1,330 & & 1,440 & 1,385 & 1,280 \\
\hline & S.E. \pm & & 45 & & 65 & 55 \\
\hline & $d 0.05$ & & 145 & & 210 & 195 \\
\hline & Mean & 1,058 & & 1,352 & & \\
\hline & S.E. \pm & & 28 & & & \\
\hline & $d 0.05$ & & 84 & & & \\
\hline $\mathbf{R Y}$ & EGRASS & & & & & \\
\hline & Moderate grazing & 1,030 & & 1,025 & 1,028 & 772 \\
\hline & Hard grazing & 425 & & 920 & 672 & 373 \\
\hline & A.S.P. & 1,035 & & 1,090 & 1,062 & 1,001 \\
\hline & S.E. \pm & & 45 & & 26 & 40 \\
\hline & $d 0.05$ & & 135 & & 78 & 140 \\
\hline & Mean & 830 & & 1,012 & & \\
\hline & S.E. \pm & & 26 & & & \\
\hline & $d 0.05$ & & 78 & & & \\
\hline $\mathbf{W}_{\mathbf{r}}$ & ITE Clover & & & & & \\
\hline & Moderate grazing & 70 & & 105 & 88 & 146 \\
\hline & Hard grazing & 61 & & 138 & 100 & 79 \\
\hline & A.S.P. & 105 & & 96 & 100 & 98 \\
\hline & S.E. \pm & & 13 & & 12 & 15 \\
\hline & $d 0.05$ & & 40 & & n.s. & 59 \\
\hline & Mean & 79 & & 113 & & \\
\hline & S.E. \pm & & 8 & & & \\
\hline & $d 0.05$ & & 23 & & & \\
\hline
\end{tabular}

Salient features are the detrimental effects of both hard grazing and treading on mean yields of total herbage and ryegrass and white clover components. Under grazing as distinct from treading there is a small, statistically significant increase in total herbage and ryegrass where pasture is closed for the winter period as A.S.P. and a decrease in the yield of white clover, compared wiith moderate grazing. Total herbage and ryegrass yields from grazed paddocks 


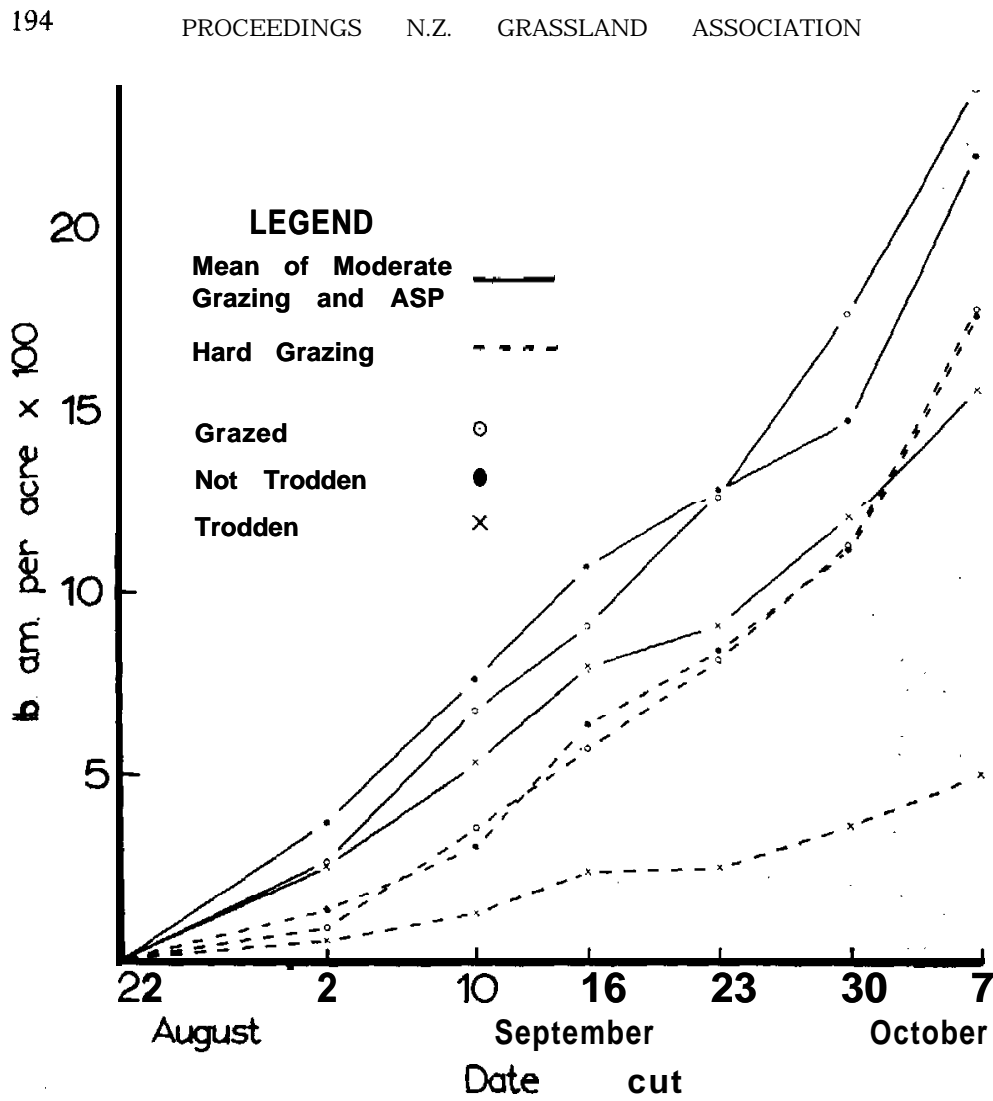

Fig. 1: Spring yields of total herbage following different winter grazing treatments.

are most closely aligned with those from the trodden plots in the treading part of the experiment.

Cumulative growth of all herbage for the period August 22 to October 7 is shown in Fig. 1. Moderate grazing and A.S.P. treatments were never different and hence the mean of these has been presented for grazing, trodden and not trodden plots.

High growth rates and final yields have been achieved from A.S.P. and moderate grazing, particularly in the not trodden plots and the paddocks, while, conversely, the severe depression in growth of the hard-grazed treatments is noteworthy, particularly in the trodden plots. Grazed paddocks and untrodden plots have performed similarly and this is most marked under hard grazing treatment. 


\section{DISCUSSION}

During winter, yields from grazed paddocks and trodden plots were similar and, because of this, results for the period may be discussed in terms of animal treading. For moderately grazed swards, winter treading had little apparent effect, but in hard grazed pasture it caused a major yield reduction. Although there was no difference at the end of this period between grazing treatments in the number of ryegrass and white clover tillers present (at August 20,1969 , there were $640 \pm 65$ ryegrass tillers and $630 \pm 147$ white clover nodes per sq. $\mathrm{ft}$ in all treatments), the pressure of defoliation and treading in hard-grazed paddocks, besides restricting root activity (Milthorpe and Davidson, 1966), may have caused a rapid turnover of the original tiller populations without giving individuals opportunity to grow and make any worthwhile contribution to yield. With moderate grazing, there must have been some deaths as a result of treading, but replacements were allowed time to grow and contribute to yield at the maximum rate permitted by temperature and light conditions at the time.

In the recovery period, grazed paddock yields were higher than those from trodden areas because of much higher rates of growth after September 2, 1969. This result is attributed to temporary damage in grazed paddocks and lasting damage in trodden areas following winter treading at different rates. Although the stocking rates in paddocks and races were similar, only $66 \%$ of the area of each treading race was walked upon and, instead of a winter treading rate of 10 sheep per acre, this approximated 15 . The latter rate was higher than that at which slight damage has been recorded for winter treading at Gore (Brown, 1968), while the former was lower.

The advantage to moderately-grazed over hard-grazed pasture persisted into the recovery period and it was not until September 30, 1969, that cumulative growth ceased to diverge. The greatest difference in growth rate occurred in the first recovery period August 22 to September 2 and there was a second period of large difference between September 23 and September 30. The small plants in the hard-grazed swards took some time to adapt themselves to the spelling regime and during this time of adaptation much of the growth effort could have been channelled into building up larger mature leaf surfaces comparable in size with those prevailing at the outset in moderately-grazed paddocks. Until this point was reached, root activity remained impaired (Milthorpe and Davidson, op. cit.) although leaf growth was accumulating and divergence of cumula- 
tive growth between grazing treatments was at a minimum (see Fig. 1, 2/29/69 to 23/9/69). After September 23, it seems highly probable that leaf surfaces in hard-grazed treatments were sufficiently large to restore root growth and much of the carbohydrate formed over the period September 23 to September 30 was used for this purpose (Milthorpe and Davidson, op. cit.) temporarily restricting accumulation of above-ground herbage. After September 30 recovery of hard winter grazed swards relative to those moderately grazed in winter was complete. The cost of hard winter grazing was $600 \mathrm{lb}$ dry herbage over a period of 40 days in early spring plus the immediate effects in winter of $500 \mathrm{lb}$ dry herbage.

The depressed winter yields of hard-grazed pastures, and particularly the residual effect of this winter management on subsequent spring production, demonstrate that a rational system of grazing must be adopted if high carrying capacities are to be achieved, for although winter feed is relatively easily provided there is total reliance on pasture for ewes and lambs in spring. The effect on teeth wear of the large soil load carried by these short pastures is another important factor (Healy and Ludwig, 1965).

The practice of autumn saving of pasture has been criticized by Brougham (1956) and this is justified when pasture is allowed to become long because of the common practice in this region of early closing. In this experiment, because of relatively late closing of pasture, height was restricted to 6 in. and spring recovery was similar to that from the moderate grazing treatment.

Systems in which sheep are removed from pastures and wintered on sawdust or straw pads or on grain crop stubble have grown in popularity. In eastern Southland-west Otago, M. J. Fitzharris (pers, comm.) noted that in winter 1968 there were some six pads capable of holding more than 200 sheep, but by 1969 the number had increased to an estimated 50 to 60 .

The moderate grazing system of this experiment can be conveniently associated with an off-winter system, as it allows pasture use when weather conditions permit and thus avoids much of the treading damage associated with wet soils (Edmond, 1962) and short pasture (Brown, 1968) which is demonstrated here in the hard-grazing treatment.

Moderate grazing is similar to that recommended in the Manawatu by Brougham (1960) and provides a flexible, highly productive pasture use system for high carrying capacity Southland farms. 


\section{WINTER GRAZINǴ MANAGEEMENT}

\section{ACKNOWLEDGEMENTS}

The technical assistance of Marion Smith and M. J. Hickey is gratefully acknowledged.

\section{REFERENCES}

Brougham, R. W., 1956: N.Z. Jl Sci. Technol., 38A: 78-87. 1960: N.Z. Jl agric. Res., 2: 125-36.

Brown, K. R., 1968: Ibid., II: 131-7.

Cutler, E. J. B., 1950: Proc. N.Z. Grassld Ass., 12: 23-30

Edmond, D. B., 1958: N.Z. Jl agric. Res., I: 319-28. 1962: Ibid., 5: 389-95,

Harris, A. J., 1960: Proc. N.Z. Grassld Ass., 22: 53-64.

Healy, W. B.; Ludwig, T. G., 1965: N.Z Jl agric. Res., 8: 737-52.

Lawlor, M. D., 1970: N.Z. agric. Sci. (in press).

Milthorpe, F. L.; Davidson, J. L., 1966: In The Growth of Cereals and Grasses, F. L. Milthorpe and J. D. Ivins (ed.), Butterworths, London. pp. 359.

Mitchell, K. J.; Glenday, A. C., 1958: N.Z. Jl agric. Res., I: 305-18. Wallace, L.R., 1959: Proc. N.Z. Grassld Ass., 21: 86-96.

\section{DISCUSSION}

Asked by Douglas to expand on the effects of variable root growth resulting from winter management on early spring top growth of pasture, Brown replied that he had no evidence of his own on that aspect which had been reported on by Davidson, at Nottingham University Easter School of Agriculture. Evans commented that the most relevant point was that phosphate uptake was inhibited until root growth recommenced. There was insufficient carbohydrate. It was round that there was a critical defoliation level for ryegrass. Brown stated that the defoliation of hard-grazed pastures was to ground level. O'Connor commented that the tiller populations in the two grazing systems were similar at the end of winter, but he wondered if there was any difference in tiller size. Brown replied that the tillers from the hard-grazing system were much smaller than those from the other systems. McQueen suggested that the hard-grazing treatment described approached set stocking in frequency of defoliation and he asked what the effect would be of lengthening the grazing interval without reducing intensity. Brown felt that with more time for recovery the result would probably be intermediate beween those obtained for hard and for moderate grazing. 